\title{
The Impact of Brand Love on Constructive and Defensive e- WOM Intentions of Consumers: The Moderating Role of e- WOM Valence
}

\author{
Kübra Tekbıyı** \\ Marmara University
}

\author{
İrem Eren Erdoğmuş** \\ Marmara University
}

\begin{abstract}
In today's digital era, electronic word-of-mouth (e-WOM) is an important communication tool positively or negatively affecting consumer behavior; however, it also poses challenges to firms since they cannot control its creation and dissemination. Brand love, the focus of brand management research in the past years, is known to create consumer loyalty and positive WOM. Therefore, this study aims to understand whether brand love can be a solution to preserve brands from negative e-WOM or augment its reputation with the spread of positive e-WOM. A multi-group experimental design was developed to test the hypotheses on Twitter users. Results show that in the case of positive tweets, the effect of brand love on producing constructive viral reactions is positive. In the case of negative tweets, the effect of brand love on producing defensive viral reactions is not significant. The results also confirm that the components of interpersonal love are valid for the brand love concept, with passion being the strongest.
\end{abstract}

Keywords: Brand Love, e-WOM, e-WOM Valence, Viral Behavior, Social Media, Twitter.

JEL Classification: M310

\section{Elektronik Ağızdan Ağıza İletişimin Valansı, Marka Așkı'nın Müşterilerin Ağızdan Ağıza İletişim Niyetleri Üzerindeki Etkisine Nasıl Aracılık Eder?}

\begin{abstract}
Özet
İçinde bulunduğumuz postmodern dijital çağda, elektronik ağızdan ağıza iletişim, tüketici davranışlarını olumlu ya da olumsuz yönde etkileyebilen önemli bir iletişim aracı olmakla birlikte, ortaya çıkışı ve yayılışını kontrol edemedikleri için şirketler için zorluk çıkarmaktadır. Marka yönetimi araştırmalarının son yıllardaki odağı olan marka aşkının, sadakat ve olumlu ağızdan ağıza iletişime yol açtığı bilinmektedir. Bu çalışma ile, markaları olumsuz ağızdan ağıza iletişimden korumada ya da olumlu ağızdan ağıza iletişimle markaların şöhretini perçinlemede marka aşkının bir çözüm olup olmayacağının anlaşılması amaçlamaktadır. Hipotezleri Twitter kullanıcıları üzerinde test etmek üzere çoklu grup deneyinden faydalanılmıştır. Sonuçlar olumlu tweete maruz kalındığında, marka aşkının yapıcı viral tepki verilmesine etkisinin olumlu olduğunu; olumsuz tweete maruz kalındığında ise, marka aşkının yıkıcı viral tepki verilmesi üzerinde bir etkisi olmadığını göstermektedir. Sonuçlar ayrıca kişiler arası aşkın bileşenlerinin marka aşkı için de geçerli olduğunu doğrulamış ve en güçlü bileşenin tutku olduğunu göstermiştir.
\end{abstract}

Anahtar Kelimeler: Marka Aşka, Elektronik Ağızdan Ağıza İletişim, Elektronik Ağızdan Ağıza İletişim Valansı, Viral Davranıs, Sosyal Medya, Twitter.

JEL Sinıflandırması: M310

\footnotetext{
* Kübra Tekbiyı. Marmara University, Goztepe Campus, 34722, Kadikoy/Istanbul. Email: kubratekbiyik@yahoo.com. Phone: +905359385446. ORCID: 0000-0003-0162-0706

** İrem Eren Erdoğmuş, Professor. Department of Business Administration. Marmara University, Goztepe Campus, 34722, Kadikoy/Istanbul. Email: ireme@ marmara.edu.tr. Phone: +905326682433. ORCID: 0000-00031648-3943
}

Boğaziçi Journal Review of Social, Economic and Administrative Studies, Vol. 34, no. 1 (2020), pp. 68-82, doi: 10.21773/boun.34.1.4 
7 The Internet and social media channels provide consumers with rich and accessible platforms for interacting with each other through sending and receiving reviews and comments about their experiences, changing the form of traditional word-of-mouth into an electronic form, called e-WOM (Hennig-Thurau et al, 2004; Sun et al, 2006). Owing to anonymity and exemption from facing social consequences, people can share their own experiences and trust each other's information easily and confidently on the Internet and social media channels. Thus, brand-related messages are uncontrollably diffused online, reaching both acquaintances and strangers who may or may not look for them (Sun et al., 2006; Chaiwongkachon, 2008). Given that e-WOM proves to be more powerful than advertising (Chen et al, 2016), it can positively or negatively affect the awareness, attitude, and purchase behavior of individuals who are exposed to it (Park and Lee, 2009; Liu, 2006; Bickart and Schindler, 2001; Kim et al, 2016). Thus, it has become an important topic of interest in the academic literature, and more research is called for to understand and control its nature in order to help marketing practices (Verhagen et al, 2013).

e-WOM can pose challenges to firms since they cannot control their creation and dissemination. They might, however, find a way to control its antecedents (ie., personal reputation, self-enhancement, sense of belonging, doing public good, problem-solving, the joy of helping others) to create positive e-WOM rather than a negative one (Cheung and Lee, 2012; Hennig-Thurau et al, 2004; Presi et al., 2014; Chu and Kim, 2011). As such, brand love, "the degree of passionate emotional attachment a satisfied consumer has for a particular trade name" (Carroll and Ahuvia, 2006, p.81), might be a useful tool to manipulate e-WOM potential, to spread the good word or maybe block bad ones. Existing studies support the idea that brand love has an impact on positive e-WOM production (Carroll and Ahuvia, 2006; Albert et al, 2009; Wallace et al., 2014), and a defensive reaction to negative information about loved brands (Wilson et al,2017; Cheng et al., 2012). Accordingly, this paper focuses on the power of brand love and analyzes its impact on consumers' reactions (constructive or defensive) when they are faced with positive or negative e-WOM about brands. The valence of e-WOM is assumed to play a moderating role in the relationship between brand love and consumers' constructive or defensive e-WOM intentions.

The significance of this study is two-fold. First, even though there is considerable research on the impact of e-WOM on receivers in terms of attitude, purchase intention, etc. (Park and Lee, 2009; Liu, 2006; Bickart and Schindler, 2001; Kim, et al., 2016), this research diverts from them and adds to the extant literature by focusing on receivers' engagement in further e-WOM (constructive or defensive) when faced with e-WOM from somebody else, and the role of brand love in this process. Second, it contributes to the current literature by evaluating the applicability of brand love on consumers' engagement in e-WOM on social media platforms. Building a loving relationship to ensure the sustainable loyalty of consumers is deemed to be crucial in the contemporary marketing world (Bagozzi et al., 2017; Kaufmann et al., 2016). Measuring the potential influence of so-called loving relationships with brands on consumer behavior in social media is timely and necessary given the increasing power of both concepts in the current marketing context. Hence, an academic analysis in this field can be particularly fruitful in terms of addressing different perspectives and providing insight.

\section{Research on Brand Love}

Studies on consumer behavior have expanded over the past few years from focusing on merely rational consumer choices and classical decision-making processes to targeting states such as irrational buying, and especially sensory, emotional, and playful consumer responses (Roy et al., 2013). As the most emotionally intense relationship between a consumer and a brand, "brand love constitutes the main objective of brand management (Hegner et al., 2017, p. 26)". 
The conceptualization of brand love was primarily founded on Sternberg's (1986) Triangular Theory of Love. One of the earliest studies regarding brand love can be traced back to Shimp and Madden's (1988) study on consumer-object relations. Adapting Sternberg's (1986) Triangular Theory of Love, they defined consumer-object love by drawing analogies between interpersonal love and love for consumption objects. Sternberg (1986) states that love is an outcome of three psychological processes, namely, emotion, motivation, cognition. Each process corresponds to a component: intimacy (closeness, bondedness, warmth, mutual understanding, support); passion (romance, physical consummation, attractiveness); and decision/commitment (short and long-term intention to love and maintain love) respectively (Sternberg, 1986; Sternberg and Grajek, 1984; Diessner et al., 2004). The Triangular Theory of Love rules that love can be explained with these three components. A combination of these components or absence of them leads to various types of relationships, such as liking when there is only intimacy, or succumbed desire when passion and decision are present (Sternberg, 1986; Shimp and Madden, 1988).

Relying on interpersonal love theories to explain brand love has been a source of disagreement in the brand management literature (Carroll et al., 2006; Batra et al., 2012; Langner et al., 2015). One of the main resources of this disagreement is the presumption stating that relationships occur between two active and reciprocating partners. Brands are non-living beings, thus, they cannot be reciprocating partners in relationships. Therefore, this raises the question of whether brand love can be explained via interpersonal love theories or not (Whang et al., 2004). Huber et al. (2015) also argue that brand love should not be studied based on interpersonal love as its characteristics are not completely analogous to the feelings experienced while liking or loving a person. They underline that interpersonal love is a consequence of bidirectional interaction, while brand love is unidirectional. Likewise, Langner et al. (2015) claim that the emotional nature of interpersonal love and brand love is significantly different. Interpersonal love is complemented by stronger emotions compared to brand love and brand love is more similar to interpersonal liking (Langner et al., 2015) While a consumerbrand relationship is often affected by rational advantages, interpersonal love is mostly altruistic. Both Langner et al. (2015) and Huber et al. (2015) show in their studies that love in brand relations is driven by rational aspects.

Yet, other studies show that interpersonal love and brand love resemble each other. The transfer of interpersonal love theories to the field of marketing continued after Shimp and Madden's (1988) attempt. Fournier (1998) was the first researcher to conduct a study on consumer-brand relationships. Accordingly, similar to interpersonal relationships, Fournier (1998) believed that consumers can even establish emotional relations with certain consumption objects such as brands and identified a total of six relationships: love and passion, self-connection, commitment, interdependence, intimacy, and brand partner quality. She defined brand love as "the degree of passionate emotional attachment a satisfied consumer has for a particular trade name" (1998, p. 363). Whang et al. (2004) adopted Lee's (1977) colors of love theory and concluded that "bikers' love toward their motorcycles resembles an interpersonal love that is passionate, possessive and selfless in nature" (p. 320). Criticizing the fact that most of the brand love literature is based on interpersonal love theories, Albert et al. (2009) carried out exploratory studies and developed their brand love scale, saying that brand love is a multidimensional concept which covers two macro components, "affection" and "passion". One of the findings of their study, however, was that brand love is highly similar to interpersonal love (Albert et al., 2009). Albert and Valette-Florence (2010), later on, adopted scales from various interpersonal love theories to form their two-dimensional brand love measure. In line with these scholars, this study adopts interpersonal love theories to explain brand love, as brands are perceived as reciprocating partners since all marketing actions - 
execution of marketing plans and tactics- regarding a brand are interpreted as reciprocal behaviors of that brand towards its users (Shimp and Madden, 1988; Fournier, 1998). Even though brands are non-living beings, the collection of perceptions formed by customers via marketers' actions personalizes them and makes them a relationship partner who can start, sustain and destroy their relationships with customers (Fournier, 1998).

The love relationship between consumers and brands has been proven to exist in online contexts as well. Wallace et al.'s work (2014) is noteworthy in this respect. Their study concluded that there is a positive relationship between self-expressive brands that are "liked" or "engaged with" on Facebook and brand love. Furthermore, brand love is found to mediate the relationship between brands and WOM. Vernuccio et al. (2015) searched for antecedents of brand love in online communities and found that social-interactive engagement influences social identity directly and brand love indirectly through the full mediating effect of social identity in online environments. In a study conducted by Chen et al. (2014), it was found that brand love influences the perception of a brand's Facebook page's ease of use. According to Hudson et al.'s study (2015), engagement with brands on social media increases the love for brands. One of the findings of the study carried out by Karjaluoto et al. (2016) is that brand love has a positive effect on e-WOM and this relation is stronger when a consumer has more experience with the brand. Wallace et al., (2017), working on brand-self congruence, found that higher self-brand congruence with a "liked" brand on Facebook predicts brand love and eWOM. Loureiro et al., (2017) found that brand love mediates the relationship between online consumer-brand engagement and positive e-WOM, and that brand love has a stronger influence on e-WOM than satisfaction.

\section{e-WOM on Social Media Networks}

Social media networks such as Twitter, Facebook, or Instagram provide platforms for individuals to connect, create, and share online content (Boyd and Ellison 2008). They create non-geographically bound brand communities, which can be described as "a structured set of social relationships among admirers of a brand" (Muniz and O'Guinn, 2001, p.412). Consumers exchange opinions among themselves about brands or products, engaging in a form of WOM communication on social media platforms that are known as e-WOM. (Cvijikj and Michahelles, 2013). Hennig-Thurau et al. (2004) defined e-WOM as "any positive or negative statement made by potential, actual, or former customers about a product or company, which is made available to a multitude of people and institutions via the Internet" (p. 39). e-WOM can be driven by consumers' motivations to give a company "something in return" for a positive experience, as well as to maintain and support the continued success of the company (Hennig-Thurau et al., 2004). The reverse is also possible. e-WOM on social media platforms is slightly different from traditional WOM (Kozinets et al., 2010). First, e-WOM on social media networks do not occur only among real-life acquaintances but also with strangers (Sun et al., 2006; Chevalier and Mayzlin, 2006). Thus, people feel less pressured, and express their thoughts more comfortably (Phelps et al., 2004; Goldsmith and Horowitz, 2006). As e-WOM messages are produced in written format (also as image, video, and audio formats), they are also more persistent and can be easily retrieved by consumers anytime they need them (Bickart and Schindler, 2001; Hennig-Thurau et al., 2004). Finally, similar to traditional WOM, the brand-related messages on e-WOM can be positive, negative, or a mixture of both, which is called WOM valence. Negative WOM is known to be more informative for consumers and more powerful compared to positive WOM (Arndt, 1967; Herr et al., 1991; Hauser et al., 1993).

e-WOM has received mounting attention as a powerful source of information and marketing communication tool; its consequences and antecedents have attracted the attention of researchers so far. Prior empirical research has examined the impact of e-WOM on product 
sales (Chevalier and Mayzlin, 2006), consumers' decision-making processes (De Bruyn and Lilien 2008), attitudes towards the brand and the website (Park and Lee, 2009), and purchase intentions (Bickart and Schindler, 2001; Park and Lee, 2009). Other studies have also sought to understand which social factors make consumers engage in e-WOM behavior (Dellarocas, 2003; Brown et al., 2007; Steffes and Burgee, 2009; Chu and Kim, 2011).

In terms of brand love, many studies show that brand love has a positive influence on e-WOM (Wallace et al., 2014; Vernuccio et al., 2015; Karjaluoto et al., 2016). If consumers feel loving relationships with brands, they are likely to recommend these brands to their friends and acquaintances. They are more proactive to post positive comments, advocate, and recommend it to others (Loureiro et al., 2017). The literature suggests that strong brand relationships such as brand love create a link between the brand and the person's self-concept; where the brand symbolically represents whom consumers believe they are or want to be (Escalas, 2004; Fournier, 1998; Cheng et al, 2012). This loving relationship then turns consumers into brand advocates, based on what Fournier (1998) calls feelings of love encouraging a biased positive perception of the brand. People spread good words about loved brands to enhance their self-concept and image. Social media make this process easier since, as Kozinets et al. (2010) emphasized, social media already transformed e-WOM into a way of expressing oneself and influencing others. Exploring the relation among brand engagement, "liking" on Facebook, brand love and WOM, Wallace et al. (2014) identified an indirect relationship between brand love and e-WOM intention, concluding that there is a positive relationship between the self-expressive nature of brands "liked" and brand love, and that consumers who engage with inner self-expressive brands are more likely to offer e-WOM for that brand. A study focusing on brand-consumer relationships conducted by Kim et al., (2014) showed that brand followers who have a strong relationship with brands tend to retweet brand tweets to others. Thus

H1: When a positive tweet about the brand is received, brand love has a positive effect on constructive e-WOM intention.

The same reasoning seems to hold for acting defensively towards negative e-WOM about loved brands. Fournier (1998) discussed in her seminal work that brand advocacy resulting from brand love can also lead to accepting wrongdoing of the brand or having biased attributions of blame. Batra et al. (2012) also talked about consumers' resistance to negative information as a result of their love for the brand. Cheng et al. (2012) discussed the idea that this is so because consumer-brand relationships are subject to self-related motivations and mechanisms (e.g., maintenance of positive self-view). Their findings showed consumers who treat the brand as self, defend the brand in failure situations, just as they would defend themselves if they failed. This is because they feel a threat to their self-concept when the brand fails and defend it to maintain a positive view of themselves. Self-affirmation theory (Steele, 1988) is used to explain how consumers form a bond between themselves and the loved brands that are threatened with negative information. Similar to Cheng et al. (2012), Wilson et al. (2017) also confirmed that having a close personal connection to brands leads consumers to process negative e-WOM messages defensively. According to his work, a counterintuitive favorable effect results from the self-brand connection. When a self-brand connection is formed, negative information regarding the brand is seen as a threat to the self, and a psychological defense mechanism is formed where consumers fight against the threatening information (Sherman and Cohen, 2006). Thus $\mathbf{H}_{2}$ : When a negative tweet about the brand is received, brand love has a positive effect on defensive e-WOM intention. 


\section{Methodology}

\section{Design and Sample of the Study}

An online survey method was used for data collection. For this study, Twitter was chosen as the social media platform because of its informal and spontaneous nature that encourages users to connect to and interact with large communities (Sousa et al., 2010). These characteristics make Twitter an ideal platform for e-WOM communication (Jansen et al., 2009). Moreover, it is one of the most popular social networking and micro-blogging sites and has more than 313 million monthly active users (https://about.twitter.com/company). The questionnaire started by asking the subjects if they used Twitter to eliminate those who did not use Twitter. Then, they were asked questions measuring the components of brand love based on Shimp and Madden's brand love model to understand their relationship with the fashion brand they followed on Twitter and recently purchased from. The fashion category was chosen as consumers can have love relationships with brands they use to construct their identities, exerting high levels of selfbrand connection (Batra et al., 2012; Ahuvia, 2005; Wilson et al., 2017).

A scenario-based experimental design was employed to understand the impact of a negative versus a positive tweet on the brand love-e-WOM intention. Two tweets were prepared, one with a positive and the other one with a negative tweet on consumers' loved brands. Respondents were told that the tweets were about the brands they had completed the brand love questionnaire for. The positive tweet read "the only brand, not a single item from it upsets me... As if it read my mind...it can be the only explanation why I find what I dream for in its stores"; and the negative tweet read "who buys from ....? Everything upsets me. Nothing is catchy or interesting. I can find nothing I dream of in its stores", respectively. Each group was then asked to answer questions related to how they would react to these tweets, constructive and defensive e-WOM. Respondents were presented both of these tweets and read the hypothetical positive/ negative tweet and were asked to express how they would react to these tweets (constructively or defensively).

Respondents were chosen using a convenience sampling method. A total of 210 participants completed questionnaires. The participants were mostly single and female $(82.86 \%, 71.90 \%$ respectively), aged between $21-30(74.29 \%)$, and university students or graduates $(56.67 \%)$. Twitter activities and Twitter usage frequencies of the participants were measured. According to the results, participants were mostly engaged in reading tweets and retweeting ( $92.38 \%$ and $63.81 \%$ respectively). Finally, almost half of them used Twitter at least a few times a day $(49.52 \%)$.

\section{Measures}

Brand love was measured by adapting the items developed by Sternberg (1986) to measure interpersonal love. A forward and backward translation methodology by two volunteer native interpreters was applied to ensure semantic and conceptual equivalence between the source language (English) and the questionnaire language (Turkish), and to minimize problems that can be created by lack of normative equivalence (Brancato et al., 2006). The authors, on the other, listed the possible constructive and defensive reactions within the possibilities of Twitter and incorporated them as items into the questionnaire to measure e-WOM intention (constructive and defensive). Each of these constructs was measured by a 5-point Likert scale, "1" being "strongly disagree" and "5" being "strongly agree". The items and variables can be found in Table 1. 


\section{Findings}

Before hypotheses testing, reliability and construct validity scores were examined to ensure the appropriateness of the research instrument. According to the results, all constructs are considered valid and reliable. The factor loadings belonging to the items are above 0.50 and they range between 0.572 and 1.037, and t-values are significant as well. Composite Reliability Coefficients is higher than 0.70 and it ranges from 0.811 to 0.956 . Hence, it shows all of the scales are reliable. All AVE scores are above 0.50 which ranges between 0.594 and 0.880 (Table 1).

Table 1 Reliability Coefficients for Constructs

\begin{tabular}{|c|c|c|c|c|c|}
\hline Construct and Indicators & $\begin{array}{c}\text { Factor } \\
\text { Loading }\end{array}$ & t-value & $\begin{array}{c}\text { Cronbach's } \\
\text { Alpha }\end{array}$ & $\begin{array}{l}\text { Composite } \\
\text { Reliability }\end{array}$ & $\begin{array}{c}\text { Average } \\
\text { Variance } \\
\text { Extracted }\end{array}$ \\
\hline \multicolumn{6}{|l|}{ First-order } \\
\hline Constructive Viral Intention & & & 0.86 & 0.811 & 0.594 \\
\hline I would share this tweet in my other social networks & 0.833 & & & & \\
\hline I would retweet this tweet with a supportive comment & 0.620 & 8.929 & & & \\
\hline Defensive Viral Intention & & & 0.86 & 0.870 & 0.694 \\
\hline I would write opposing comments for this tweet & 0.940 & 11.160 & & & \\
\hline I would retweet this tweet with an opposing comment & 0.867 & 10.921 & & & \\
\hline \multicolumn{6}{|l|}{ Second-order } \\
\hline Brand Love & & & 0.874 & 0.956 & 0.880 \\
\hline Commitment & 0.863 & & & & \\
\hline I can't imagine ending my relationship with this brand & 0.779 & & & & \\
\hline I couldn't let anything get in the way of my commitment to this brand & 0.601 & 7.782 & & & \\
\hline I have confidence in the stability of my relationship with this brand & 0.572 & 7.423 & & & \\
\hline Intimacy & 0.906 & & & & \\
\hline I have a relationship of mutual understanding with this brand & 0.741 & & & & \\
\hline I experience great happiness with this brand & 0.626 & 9.592 & & & \\
\hline I value this brand greatly in my life & 0.801 & 10.266 & & & \\
\hline Passion & 1.037 & & & & \\
\hline I find this brand very attractive physically & 0.690 & & & & \\
\hline I cannot imagine life without this brand & 0.687 & 8.869 & & & \\
\hline
\end{tabular}

Note: All loadings are significant at level $\mathrm{p}<0.001$ with a 2,000 sample bootstrapping procedure.

According to the results of discriminant validity assessment, all variables reflect distinct concepts. The square root of AVE is higher than correlations with others. For example, brand love's square root of AVE (0.938) is higher than the correlation coefficients of all other variables (Table 2). The result of the second-order factor analysis confirms that three dimensions, namely intimacy, passion, and commitment explain the brand love concept, passion scoring the highest.

Table 2 Correlations of Latent Variables

\begin{tabular}{|l|r|r|r|}
\hline & CeWOMI & BRAND_LOVE & DeWOMI \\
\hline CeWOMI & 0,770 & & \\
\hline BRAND_LOVE & 0,302 & 0,938 & \\
\hline DeWOMI & 0,641 & 0,062 & 0,833 \\
\hline
\end{tabular}

Diagonal cells are the square root of AVE.

Ce-WOMI: Constructive e-WOM Intention; DeWI: Defensive e-WOM Intention

The model for constructive e-WOM intention showed good fit where $x^{2}: 41.398 \mathrm{df}: 24$, p: .015 CFI: .983 TLI: .968 RMSEA: .042 PCLOSE: .720, which indicate the model fit the data well. The structural model was evaluated using standardized path coefficients, their significance level (t-statistic), and $\mathrm{R}^{2}$ estimates. The $\mathrm{R}^{2}$ of constructive e-WOM intention is 
0.20, which is greater than the recommended value of 0.10 (Falk and Miller, 1992). For positive tweet exposed respondents, the effect of brand love on producing constructive e-WOM reactions in the face of the positive tweet is positive and statistically significant $(\beta=0.45, \mathrm{t}=$ $3.964, \mathrm{p}<0.001$ ), which shows that H1 is supported (Figure 1). The model for defensive eWOM intention also shows good fit where $\mathrm{x}^{2}: 36,114 \mathrm{df}: 24$, p: .054 CFI: .990 TLI: .981 RMSEA: .035 PCLOSE: .860, which indicated the model fit the data well. The structural models were evaluated using standardized path coefficients, their significance level (t-statistic), and $\mathrm{R}^{2}$ estimates. According to the results, $\mathrm{H} 2$ is not supported: The $\mathrm{R}^{2}$ of defensive e-WOM intention in the face of negative tweet is 0.01 , which is inadequate for the recommended value of 0.10 (Falk and Miller, 1992). For negative tweet exposed respondents, the effect of brand love on defensive e-WOM reactions is insignificant $(\beta=0.09, \mathrm{t}=0.702, \mathrm{p}<0.001)$.

Figure 1 Effect of Brand Love on Constructive e-WOM Intention in the face of Positive Tweet.

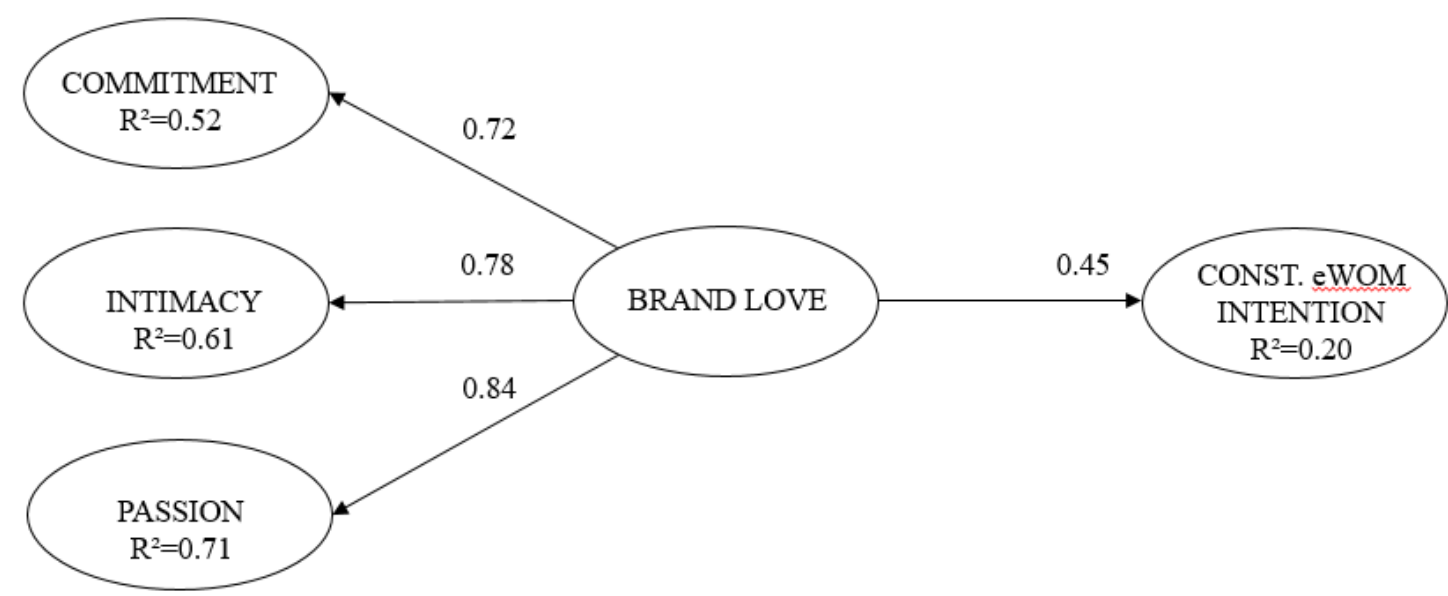

\section{Discussion and Conclusion}

The present research examined the impact of brand love on consumers' constructive e-WOM reactions and consumers' defensive e-WOM reactions when they receive a positive versus negative e-WOM. Previous literature already confirmed that brand love has a positive effect on positive e-WOM of consumers (Wallace et al., 2014; Vernuccio et al., 2015; Karjaluoto et al., 2016). This study extended the previous studies by adding e-WOM valence as a moderator on this proven relationship and, in this way, explore the possibilities of defensive e-WOM intentions to add to the literature. The results showed that consumers' reactions to e-WOM messages vary based on the valence of the e-WOM received. When participants were exposed to a positive tweet about their beloved brand, brand love led to constructive e-WOM intentions. In other words, consumers said that they would further spread the good word not only on Twitter but also on other social networks, and write extra positive comments. When consumers were faced with a negative tweet about their loved brand, on the other hand, it was expected that they would react defensively and protect the brand as they would defend themselves, similar to the results of the study by Wilson et al. (2017) and Cheng et al. (2012). However, the results proved that was not so. Brand love did not lead to defensive e-WOM intention when participants witness a negative tweet about their brands. Consumers by no means were prone to act to defend their brand. This result contradicted the results in the extant literature (Wilson et al., 2017; Cheng et al., 2012) and needs to be explored through further research. 
The finding that defensive action is not taken against a negative tweet about a loved brand is surprising. First of all, clothing is an identity relevant category, which may create stronger bonding or self-identification between the consumer and the loved brand and can lead consumers to engage in counterintuitive and defensive responses (Wilson et al., 2017). There may be some reasons why it did not so. The medium in the study, Twitter may be one of these reasons. When looking into the reasons why people use Twitter, the literature shows that people use Twitter for mostly "peaceful" reasons like keeping in touch with acquaintances, raising visibility for interesting things, gathering information, seeking opinion (Java et al., 2007; Zhao and Rosson, 2009; Naaman et al., 2010). Thus, this fact may lend support to the findings of research about the spreading of positive tweets and not engaging in "defensive" actions as a result of this dominant peaceful atmosphere. Writing a negative tweet raises interest in others, and consumers may become involved with tweeting traffic that would not be pleasant. Another reason for not taking action against negative tweets might be that retweeting the negative tweet even with a negative comment will ensure visibility for the brand-related negative comment, which will lead to the unintentional spread of it. Therefore, consumers may choose to leave the negative tweet as it is in order not to further spread it. Nevertheless, the findings of this research need further enhancement.

Apart from the discussion above, this study can also be approached from its contributions to Shimp and Madden's brand love model adapted from Sternberg's Triangular Theory of Love (Sternberg, 1986) in a social media context. The results confirmed that brand love has three components: intimacy, passion, and commitment. Among all of them, the passion component scored the highest, suggesting that it is the strongest component of brand love. The result is noteworthy: the intimacy vertex is more related to reciprocity; while the passion vertex is less so. It might be interpreted that reciprocity is not a priority for consumers; what they look for in a brand can be interpreted as an irresistible attraction. Moreover, the case of commitment vertex scoring less than passion, however slightly, might offer a hint that consumers don't look for commitment in their relationships with loved brands as strongly as marketers think, at least not more than passion. This might further lend credence to the idea that it is possible to love a brand even though one doesn't purchase that particular brand (maybe due to lack of means).

Overall, this study supports Shimp and Madden's brand love model in understanding consumer behavior in online contexts. Contrary to the general understanding that consumers spread negative WOM more than positive WOM, this study found that if consumers love the brand, they are likely to spread positive e-WOM on social media platforms (Twitter in this case). On the other hand, even if the consumers love the brand, they remain indifferent when faced with negative e-WOM, neither acting defensively such as blocking it, nor spreading it further at least on the Twitter platform. The study provides evidence in favor of creating marketing strategies to build a strong emotional connection, love, and passionate relationship between the consumers and brands in the digital, social media age. More studies can be constructed to understand this relationship in different social media contexts, different types of products and differing levels of brand love manipulated.

\section{Managerial Implications}

In today's world, the Internet constitutes non-negligible importance in people's lives. They consult it for various reasons not the least of which is spending some leisure time, passing time, exploring, looking for information and socializing. Thanks to social media, they are no longer a mere "audience" but have become the "co-creators" of content in the virtual world. They upload videos to Youtube, open blogs to write about their summer vacations, share the photo of a riot they come across on Instagram or an article on their Facebook accounts. There is a 
continuous and endless conversation with no or limited control among ordinary people on these social media platforms. To the fear of marketers mostly, they also share their brand-related experiences on the Internet, magnifying the effect of traditional word of mouth conversations, which are deemed more credible than advertising. A buzz started by an upset and angry customer has the power to crush a brand in the eyes of other customers. This study provides important insights for firms that operate or do marketing activities in social media. The findings imply that brand love facilitates the spread of the good word about the brand, yet, consumers remain indifferent when they are exposed to negative brand-related online messages on Twitter even though it's about their beloved brands. Thus, firms can save money by lowering their investment in fighting against negative e-WOM or preventing the exposure of negative eWOM to consumers, at least on Twitter, since the negative word does not spread as quickly as it spreads offline (Richins, 1987) on this medium. On the other hand, marketers need to look for ways to build love relationships between their brands and target customers to ensure positive online conversations spreading on Twitter. The analysis shows that customers tend to love brands that say something about who they are and communicate this message to other members of the community. This finding implies that marketers need to meticulously analyze their target segments to understand who they are and what they want to say about themselves to the rest of the world. As the literature shows that congruence between inner-self and brand is more likely to lead to brand love (Carroll and Ahuvia, 2006), marketers need to understand the longings and passions of their customers and find a way of addressing them in their communications.

\section{Further Research Implications}

First of all, this study is restricted to fashion brands, so it can be repeated in other categories to understand if hypotheses hold in those contexts as well. Second, the convenience sampling methodology may limit the generalizability of the findings. Thus, probability sampling methods may be employed in further research. To sophisticate the research, other studies may measure the self-brand connection of the consumers and understand their level of involvement within the category to provide better insight into why people do not defend their loved brands on Twitter. Another important point is that this study restricted itself to Twitter as a social media platform. The study can be applied to other social media channels to see if there are any variations in viral intentions based on the platform used. Finally, the source of the tweet may make a difference in the responses of the receivers. For example, Laczniak et al., (2001) found in their study that individuals attribute word of mouth negativity to the communicators, so that brand evaluations can be protected from negativity. Therefore, several different types of sources for tweets can be taken into account in terms of how they affect consumer responses in further studies. 


\section{References}

Ahuvia, A. (2005). "Beyond the Extended Self: Loved Objects and Consumers' Identity Narratives". Journal of Consumer Research, 32(1): 171-184.

Albert, N., Merunka, D. and Valette-Florence, P (2009). "The Feeling of Love for a Brand: Concept and Measurement". Advances in Consumer Research, 36: 300-307.

Albert, N., and Valette-Florence, P. (2010). "Measuring the love feeling for a brand using interpersonal love items". Journal of Marketing Development and Competitiveness, 5 (1): 57-63.

Arndt, J. (1967) "Role of product-related conversations in the diffusion of a new product". Journal of Marketing Research, 4: 291-295.

Bagozzi, R. P., Batra, R., \& Ahuvia, A. (2017). "Brand love: development and validation of a practical scale". Marketing Letters, 28(1), 1-14.

Batra, R., Ahuvia, A. and Bagozzi, R. P. (2012). "Brand love". Journal of Marketing, 76: 116.

Bickart, B., and Schindler, R. M. (2001). "Internet forums as influential sources of consumer information". Journal of Interactive Marketing, 15 (3): 31-40.

Boyd, D. M., and Ellison N. B. (2008). "Social network sites: definition, history, and scholarship". Journal of Computer-Mediated Communication, 13(1): 210-230.

Brancato, G., Macchia, S., Murgia, M., Signore, M., Simeoni, G., Blanke, K., Körner, T., Nimmergut, A., Lima, P., Paulino, R., \& Hoffmeyer-Zlotnik, J.H.P., (2006). Handbook of recommended practices for questionnaire development and testing in the European statistical system. $1^{\text {st }}$ edition EU: European Commission Grant Agreement 2004103000002.

Brown, J., Broderick, A. J., and Lee, N. (2007) "Word of mouth communication within online communities: conceptualizing the online social network". Journal of Interactive Marketing, 21(3): 2-20.

Carroll, B. A., and Ahuvia, A. C. (2006). "Some antecedents and outcomes of brand love". Market Lett, 17: 79-89.

Chaiwongkachon, B. (2008). "Understanding online word of mouth phenomenon amongst teenagers in Thailand". MA Dissertation, University of Nottingham, Nottingham, England.

Chen, H., Papazafeiropoulou, A., Chen, T. K., Duan, Y., and Liu, H. W. (2014). "Exploring the commercial value of social networks: Enhancing consumers' brand experience through Facebook pages". Journal of Enterprise Information Management, 27(5): 576598.

Chen, J., Teng, L., Yu, Y. and Yu, X. (2016). "The effect of online information sources on purchase intentions between consumers with high and low susceptibility to informational influence". Journal of Business Research, 69(2): 467-475.

Cheng, S. Y., White, T. B., and Chaplin, L. N. (2012). "The Effects of Self-Brand Connections on Responses to Brand Failure: A New Look at the Consumer-Brand Relationship". Journal of Consumer Psychology, 22: 280-288. 
Cheung, C. M., and Lee, M. K. (2012). "What drives consumers to spread electronic word of mouth in online consumer-opinion platforms". Decision support systems, 53(1): 218225 .

Chevalier, J. A., and Mayzlin, D. (2006). "The effect of word of mouth on sales: online book reviews". Journal of Marketing Research, 43(3): 345-354.

Chu, S. C., and Kim, Y. (2011). "Determinants of consumer engagement in electronic wordof-mouth (e-WOM) in social networking sites". International Journal of Advertising, 30(1): 47-75.

Cvijikj, I. P., and Michahelles, F. (2013). "Online engagement factors on Facebook brand pages". Social Network Analysis and Mining, 3(4): 843-861.

De Bruyn, A., and Lilien, G. L. (2008). "A multi-stage model of word-of-mouth influence through viral marketing”. International Journal of Research in Marketing, 25(3): 151163.

Dellarocas, C. (2003). "The digitization of word of mouth: Promise and challenges of online feedback mechanisms". Management Science, 49(10): 1407-1424.

Diessner, R., Frost, N., and Smith, T. (2004). "Describing the neoclassical psyche embedded in Sternberg's triangular theory of love". Social Behavior and Personality: an international journal, 32(7): 683-690.

Escalas, J. E. (2004). "Narrative processing: Building consumer connections to brands". Journal of Consumer Psychology, 14: 168-179.

Falk, R. F., and Miller, N. B. (1992). A primer for soft modelling. Akron, OH: University of Akron Press.

Fournier, S. (1998). "Consumers and their brands: developing relationship theory in consumer research". Journal of Consumer Research, 24: 343-373.

Goldsmith, R. E., and Horowitz, D. (2006). "Measuring motivations for online opinion seeking". Journal of Interactive Advertising, 6(2): 1-16.

Hauser, J. R., Urban, G. L., and Weinberg, B. D. (1993). "How consumers allocate their time when searching for information". Journal of Marketing Research, 30(4): 452-466.

Hegner, S. M., Fenko, A., and Teravest, A. (2017). "Using the theory of planned behaviour to understand brand love". Journal of Product and Brand Management, 26(1): 26-41.

Hennig-Thurau, T., Gwinner, K. P., Walsh, G., and Gremler, D. D. (2004). "Electronic wordof mouth via consumer-opinion platforms: What motivates consumers to articulate themselves on the Internet". Journal of Interactive Marketing, 18(1): 38-52.

Herr, P.M., Kardes, F.R., and Kim, J. (1991). "Effects of word-of-mouth and product attribute information on persuasion: an accessibility-diagnosticity perspective". Journal of Consumer Research, 17(4): 454-62.

Huber, F., Meyer, F., and Schmid, D. A. (2015). "Brand love in progress - the interdependence of brand love antecedents in consideration of relationship duration". Journal of Product and Brand Management, 24(6): 567-579.

Hudson, S., Roth, M. S., Madden, T. J., and Hudson, R. (2015). "The effects of social media on emotions, brand relationship quality, and word of mouth: An empirical study of music festival attendees". Tourism Management, 47: 68-76. 
Jansen, B. J., Zhang, M., Sobel, K., and Chowdhury, A. (2009). "Twitter power: Tweets as electronic word of mouth". Journal of the American Society for Information Science and Technology, 60(11): 2169-2188.

Java, A., Finin, T., Song, X. and Tseng, B. (2007). "Why we twitter: Understanding microblogging usage and communities". Joint 9th WEBKDD and 1st SNA-KDD Workshop '07, August 12, 2007, San Jose, California, USA.

Karjaluoto, H., Munnukka, J. and Kiuru, K. (2016) "Brand love and positive word of mouth: the moderating effects of experience and price". Journal of Product and Brand Management, 25(6): 527-537.

Kaufmann, H. R., Loureiro, S. M. C., \& Manarioti, A. (2016). "Exploring behavioural branding, brand love and brand co-creation". Journal of Product \& Brand Management, 25 (6): 516-526.

Kim, E., Sung, Y. and Kang, H. (2014). “Brand followers' retweeting behavior on Twitter: How brand relationships influence brand electronic word-of-mouth". Computers in Human Behavior, 37:18-25.

Kim, S. J., Wang, R. J. H., and Malthouse, E. C. (2016). “The effects of online negative word-of-mouth: An empirical study". In Obal M., Krey N., Bushardt C. (eds) Let's Get Engaged! Crossing the Threshold of Marketing's Engagement Era. Developments in Marketing Science: Proceedings of the Academy of Marketing Science. Springer, Cham.

Kozinets, R. V., de Valck, K., Wojnicki, A. C., and Wilner, S. J. S. (2010). "Networked Narratives: Understanding word-of-mouth marketing in online communities". Journal of Marketing, 74(2): 71-89.

Laczniak, R. N., DeCarlo, T. E., and Ramaswami, S. N. (2001). "Consumers' response to negative Word-of-Mouth communication: An attribution theory perspective". Journal of Consumer Psychology, 11(1): 57-73.

Langner, T., Schmidt, J., and Fischer, A. (2015). "Is it really love? A comparative investigation of the emotional nature of brand and interpersonal love". Psychology and Marketing, 32(6): 624-634.

Lee, J. A. (1977). “A Typology of Styles of Loving”. Personality and Social Bulletin, 3: 173182.

Liu, Y. (2006). "Word of Mouth for Movies: Its Dynamics and Impact on Box Office Revenue". Journal of Marketing, 70(3): 74-89.

Loureiro, S. M. C., Gorgus, T., and Kaufmann, H. R. (2017). “Antecedents and outcomes of online brand engagement: The role of brand love on enhancing electronic-word-ofmouth". Online Information Review, 41(7): 985-1005.

Muniz, A. M. Jr., and O'Guinn, T. C. (2001). "Brand community". Journal of Consumer Research, 27(4): 412-432.

Naaman, M., Boase, J., and Lai, C. H. (2010, February). "Is it really about me?: message content in social awareness streams". In Proceedings of the 2010 ACM conference on Computer supported cooperative work (pp. 189-192). ACM.

Park, C., and Lee, T. M. (2009). "Information direction, website reputation, and e-WOM effect: a moderating role of product type". Journal of Business Research, 62(1): 61-67. 
Phelps, J. E., Lewis, R., Mobilio, L., Perry, D., and Raman, N. (2004). "Viral marketing or electronic word-of-mouth advertising: Examining consumer responses and motivations to pass along email". Journal of Advertising Research, 45(4): 333-348.

Presi, C., Saridakis, C., and Hartmans, S. (2014). "User-generated content behaviour of the dissatisfied service customer". European Journal of Marketing, 48(9/10): 1600-625.

Richins, M. L. (1987). "A Multivariate Analysis of Responses to Dissatisfaction”, Journal of the Academy of Marketing Science, 15: 24-31.

Roy, S. K., Eshghi, A., and Sarkar, A. (2013). “Antecedents and consequences of brand love". Journal of Brand Management, 20(4): 325-332.

Sherman, D. K., and Cohen, G. L. (2006). "The psychology of self-defense: self-affirmation theory". Advances in Experimental Social Psychology, 38: 183-242.

Shimp, T. A., and Madden, T. J. (1988) "Consumer-Object relations: A conceptual framework based analogously on Sternberg's triangular theory of love". Advances in Consumer Research, 15: 163-168.

Sousa, D., Sarmento, L., and Rodrigues, E. M. (2010). "Characterization of the twitter @replies network: are user ties social or topical?" SMUC'10 Proceedings of the $2^{\text {nd }}$ International Workshop on Search and Mining User-Generated Contents, p. 63-70, ACM New York, USA.

Steele, C. M. (1988). "The psychology of self-affirmation: Sustaining the integrity of the self”. Experimental Social Psychology, 21: 261-302.

Steffes, E. M., and Burgee, L. E. (2009). "Social ties and online word of mouth". Internet Research, 19(1): 42-59.

Sternberg, R. J. (1986). “A triangular theory of love”. Psychological Review, 93(2): 119-135.

Sternberg, R. J., and Grajek, S. (1984). "The nature of love". Journal of Personality \& Social Psychology, 47(2): 312-329.

Sun, T., Youn, S., Wu, S., and Kuntaraporn, M. (2006). "Online word-of-mouth (or mouse): An exploration of its antecedents and consequences". Journal of Computer Mediated Communication, 11: 1104-1127.

Verhagen, T., Nauta, A., and Feldberg, F. (2013). "Negative online word-of-mouth: behavioral indicator or emotional release?" Computers in Human Behavior, 29(4): 1430-1440.

Vernuccio, M., Pagani, M., Barbarossa, C. and Pastore, A. (2015) "Antecedents of brand love in online network-based communities. A social identity perspective". Journal of Product and Brand Management, 24 (7): 706-719.

Wallace, E., Buil, I., and Chernatony, L. (2014). "Consumer engagement with self-expressive brands: brand love and WOM outcomes". Journal of Product \& Brand Management, 23(1): 33-42.

Wallace, E., Buil, I., and Chernatony, L. (2017). “Consumers' self-congruence with a "Liked" brand: Cognitive network influence and brand outcomes". European Journal of Marketing, 51(2): 367-390.

Whang, Y., Allen, J., Sahoury, N., and Zhang, H. (2004). "Falling in love with a product: The structure of a romantic consumer-product relationship". Advances in Consumer Research, 31: 320-327. 
Wilson, A. E., Giebelhausen, M. D., and Brady, M. K. (2017). "Negative word of mouth can be positive for consumers connected to the brand". Journal of the Academy of Marketing Science, 45(4): 534-547.

Zhao, D., and Rosson, M. B. (2009). "How and why people Twitter: The role of the microblogging plays in informal communication at work". GROUP'04, May 10-13, 2009, Sanibel Island, Florida, USA.

On behalf of all authors, the corresponding author states that there is no conflict of interest. 